\title{
Correction to: Does corporate social responsibility affect Generation Z purchase intention in the food industry
}

\section{Man Chung Wong ${ }^{1}$}

Published online: 4 December 2021

(C) The Author(s) 2021

\section{Correction to: Asian J Bus Ethics https://doi.org/10.1007/s13520-021-00136-9}

The original article has been corrected. During production of the article, the author name was represented incorrectly on the article. This is now correct.

Open Access This article is licensed under a Creative Commons Attribution 4.0 International License, which permits use, sharing, adaptation, distribution and reproduction in any medium or format, as long as you give appropriate credit to the original author(s) and the source, provide a link to the Creative Commons licence, and indicate if changes were made. The images or other third party material in this article are included in the article's Creative Commons licence, unless indicated otherwise in a credit line to the material. If material is not included in the article's Creative Commons licence and your intended use is not permitted by statutory regulation or exceeds the permitted use, you will need to obtain permission directly from the copyright holder. To view a copy of this licence, visit http://creativecommons.org/licen ses/by/4.0/.

Publisher's note Springer Nature remains neutral with regard to jurisdictional claims in published maps and institutional affiliations.

The online version of the original article can be found at https://doi.org/10.1007/s13520-021-00136-9

Man Chung Wong

albertwong@ln.edu.hk

1 Department of Marketing and International Business, Lingnan University, Hong Kong, Hong Kong 